S

\begin{tabular}{|l|l|}
\hline $\begin{array}{l}\text { 2. To: (Recelving Organization) } \\
\text { Distribution }\end{array}$ & $\begin{array}{l}\text { 3. From: (Originating Organlzation) } \\
\text { TOPS }\end{array}$ \\
\hline $\begin{array}{l}\text { 5. Proj./Prog./Dept./Div.: } \\
\text { RPP }\end{array}$ & $\begin{array}{l}\text { 6. Desion Authority/Design Agent/Cog. Engr: } \\
\text { D. L. Herting }\end{array}$ \\
\hline
\end{tabular}

8. Originator Remarks:

Test plan for approval and release

4. Related EDT No.:

$\mathrm{N} / \mathrm{A}$

7. Purchase Order No.:

N/A

9. Equip./Component No.:

$\mathrm{N} / \mathrm{A}$

10. System/Bldg./Faclity:

222-SA Laboratory

12. Major Asem. Dwg. No.:

N/A

13. Permit/Permlt Application No.:

$\mathrm{N} / \mathrm{A}$

14. Required Response Date:

$07 / 14 / 00$
15.

\begin{tabular}{|l|l|}
\hline $\begin{array}{c}\text { (A) } \\
\text { tem } \\
\text { No. }\end{array}$ & (B) Document/Drawing No. \\
\hline 1 & HNF-6519 \\
\hline & \\
\hline & \\
\hline & \\
\hline & \\
\hline
\end{tabular}

16.

\begin{tabular}{|c|lc|}
\hline Approval Designator (F) & \multicolumn{2}{c}{ Reason for Transmittal (G) } \\
\hline E, S, Q, D OR N/A & 1. Approval & 4. Review \\
(See WHC-CM-3-5, & 2. Release & 5. Post-Review \\
Sec. 12.7) & 3. Information & 6. Dist. (Receipt Acknow. Required)
\end{tabular}

KEY
DATA TRANSMITTED

$\begin{array}{lll}\text { (C) Sheet } & \text { (D) Rev. } & \text { (E) Title or Description of Data Transmitted }\end{array}$
(F)
(C)

)

\begin{tabular}{|c|c|c|c|}
\hline (F) & (C) & (H) & (I) \\
\hline $\begin{array}{l}\text { Approval } \\
\text { Desig- } \\
\text { nator }\end{array}$ & $\begin{array}{c}\text { Reason } \\
\text { or Trans } \\
\text { mittal }\end{array}$ & $\begin{array}{l}\text { Oriof } \\
\text { nator } \\
\text { Dispo- } \\
\text { ction }\end{array}$ & $\begin{array}{c}\text { Receiv- } \\
\text { or } \\
\text { Diepo- } \\
\text { sition }\end{array}$ \\
\hline $\mathbf{E}$ & 1 & 1 & \\
\hline & & & \\
\hline & & & \\
\hline & & & \\
\hline & & & \\
\hline & & & \\
\hline & & & \\
\hline
\end{tabular}

17

\begin{tabular}{|c|c|c|c|}
\hline $\begin{array}{l}\text { (G) } \\
\text { Rea- } \\
\text { son }\end{array}$ & $\begin{array}{c}(\mathrm{H}) \\
\text { Disp. }\end{array}$ & (K) Signature & (L) Date (M) MSIN \\
\hline & & \multicolumn{2}{|l|}{ Design Authority } \\
\hline & & \multicolumn{2}{|l|}{ Design Agent } \\
\hline 1 & 1 & Cog. Eng. D.L. Herting & T6-07 \\
\hline \multirow[t]{3}{*}{1} & 1 & Cog.Mgr. L.L. Lockrem & $-16-07$ \\
\hline & & QA & \\
\hline & & Safety & \\
\hline 1 & 1 & R.J. Boom & $7 / 18 / 00^{\mathrm{T} 6-14}$ \\
\hline
\end{tabular}

Danflet

D.L. Herting

Signature of EDT

Originator

\section{$7 / 10 / 00$ Date}

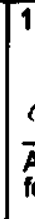

20.

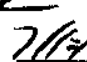

Authorized Representative for Receiving Organization

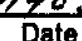

Date gnator for required signatures)

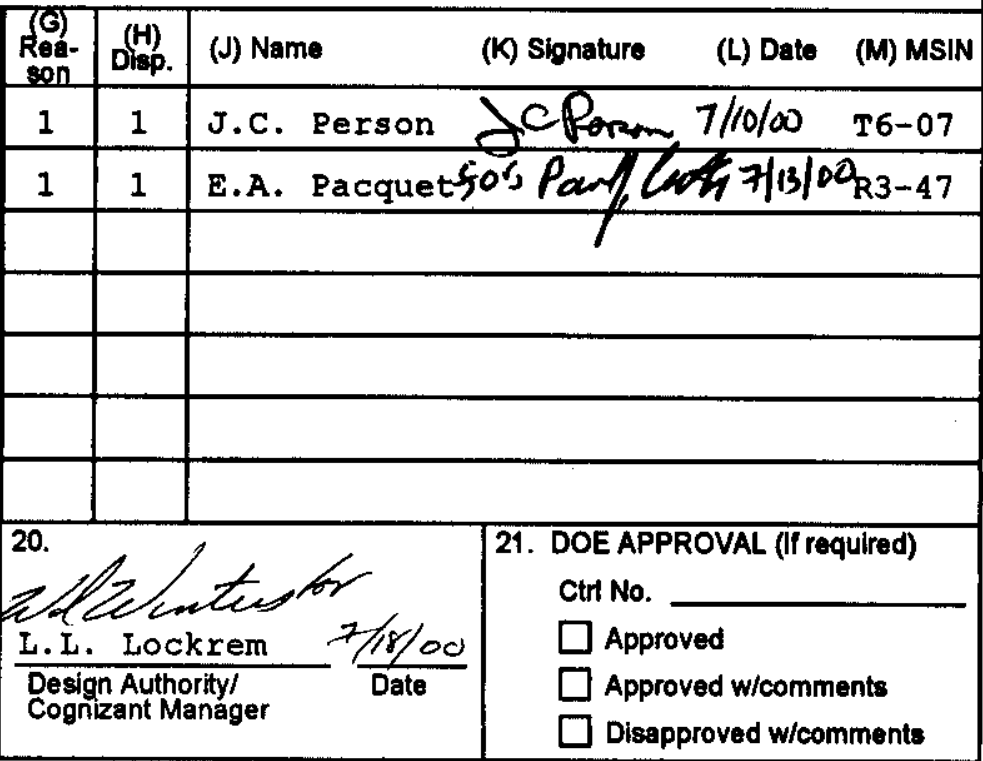


HNF-6519, Rev. 0

\title{
Test.Plan for Simulated Saltcake Retrieval Test
}

\author{
D. I. Herting and J. C. Person \\ Fluor Hanford \\ Richland, WA 99352 \\ U.S. Department of Energy Contract DE-AC06-96RL13200
}

\author{
EDT/ECN: 620372 \\ UC: 2030 \\ Org Code: 8D500 \\ Charge Code: 112107 \\ B\&R Code: EW3130010 \\ Total Pages: 15
}

Key Words: saltcake, retrieval, simulant, dissolution, solubility, saltwell, sodium, nitrate, salt

Abstract: This document describes the plan for a bench-scale laboratory test to evaluate physical and chemical parameters associated with dissolution of a simulated saltcake waste. Parameters to be measured during the test include water addition rate, liquid drainage rate, visual observations of flow patterns, physical appearance and volume of dissolving saltcake, chemical composition of drained liquid, and polarized light microscopy analysis of solids.

TRADEMARK DISCLAIMER. Reference herein to any specific commercial product, process, or service by trade name, trademark, manufacturer, or otherwise, does not necessarily constitute or imply its endorsement, recommendation, or favoring by the United States Government or any agency thereof or its contractors or subcontractors.

Printed in the United States of America. To obtain $\infty$ ples of this document, contact: Document Control Services, P.O. Box 950, Mailstop H6-08, Richland WA 99352, Phone (509) 372-2420; Fax (509) 376-4989.

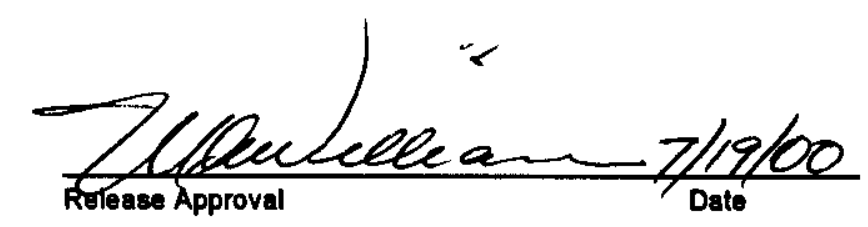

Approved For Public Release

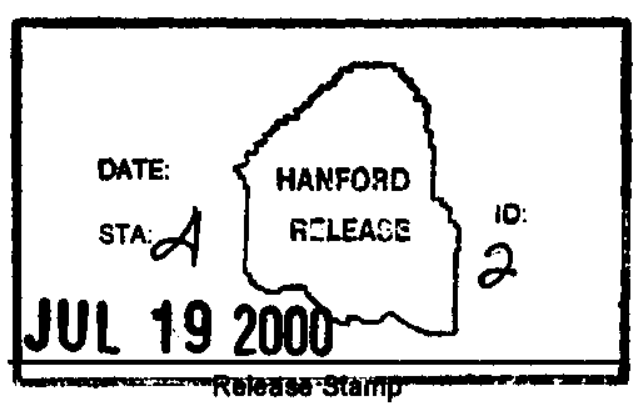

Roterofostainip 
HNF-6519, Rev. $O$

\section{Contents}

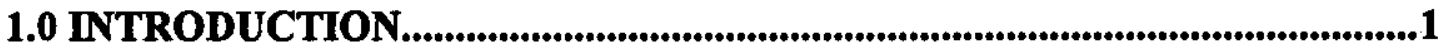

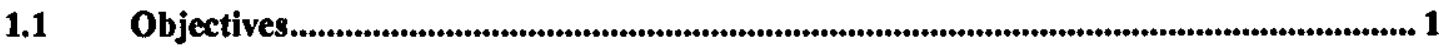

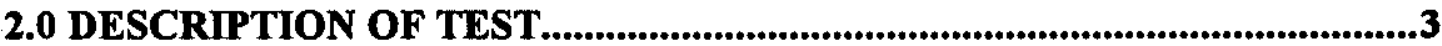

2.1 Simulant Selection and Composition ......................................................................................... 3

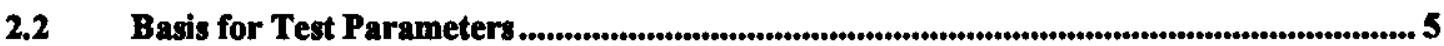

2.3 Instrumentation and Measurements..........................................................................................6 6

2.4 Changing the Test $\ldots$

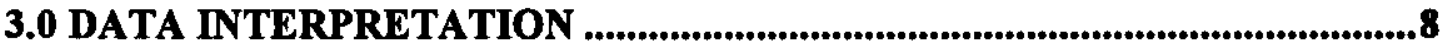

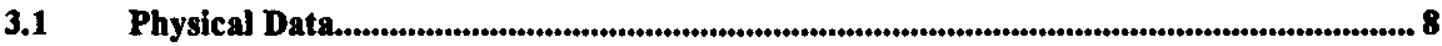

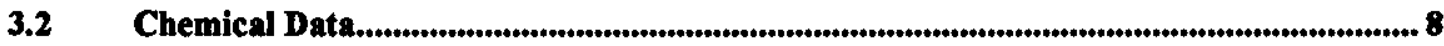

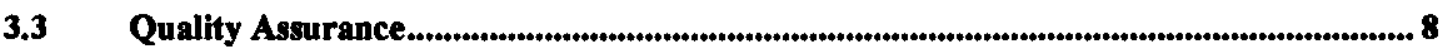

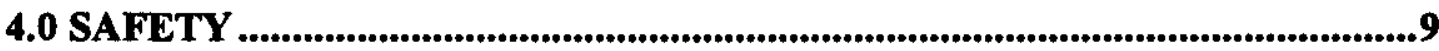

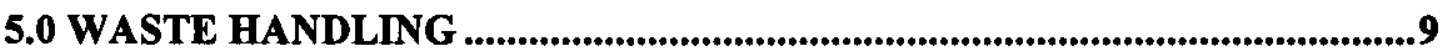

6.0 SCHEDULE AND DELIVERABLES.................................................10

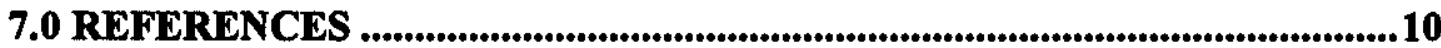

Table 2-1. Core Sample and Simulant Concentrations in Weight Percent............4

Figure 2-1. Diagram of Saltcake Layer in Single Shell Tank................................5

Appendix A. Waste Stream Fact Sheet

Appendix B. Waste Compatibility Assessment 


\section{Acronyms and Abbreviations}

$\begin{array}{ll}\text { BY-106 } & \text { single shell tank 241-BY-106 } \\ \mathrm{cm} & \text { centimeter(s) } \\ \mathrm{ft} & \text { foot (feet) } \\ \text { IC } & \text { ion chromatography } \\ \text { ICP } & \text { inductively coupled plasma spectroscopy } \\ \text { in } & \text { inch(es) } \\ \text { m } & \text { meter(s) } \\ \text { PLM } & \text { Polarized Light Microscopy } \\ \text { S-102 } & \text { 24l-S-102 } \\ \text { SpG } & \text { specific gravity (or density) } \\ \text { TIC/TOC } & \text { total inorganic carbon/total organic carbon } \\ \text { TOPS } & \text { Technical Operations and Process Science }\end{array}$




\subsection{INTRODUCTION}

This document describes the plan for a bench-scale laboratory test to evaluate physical and chemical parameters associated with dissolution of a simulated saltcake waste. The composition of the simulant will be based on core sample analytical results for the saltcake layer in tank 241-S-102 (S-102), with some minor modifications explained in detail in Section 2.1. Testing will take place in the 222-SA laboratory.

A likely scenario for retrieving saltcake from single shell tanks is the "Rainbird ${ }^{\oplus}$ sprinkler" method. Water is distributed evenly across the surface of the saltcake and allowed to percolate by gravity through the waste. The salt dissolves in the water, forming a saturated solution. The saturated liquid is removed by a saltwell pump situated near the bottom of the tank. By this method, there is never a large inventory of liquid in the tank that could pose a threat of leakage.

There are many variables or factors that can influence the hydrodynamics of this retrieval process. They include saltcake porosity; saltwell pumping rate; salt dissolution chemistry; factors that could promote flow channeling (e.g. tank walls, dry wells, inclusions or discontinuities in the saltcake); method of water distribution; plug formation due to crystal formations or accumulation of insoluble solids. A brief literature search indicates that very little experimental data exist on these aspects of saltcake dissolution (Wiersma 1996, 1997).

\subsection{Objectives}

The proposed test will provide a first characterization of water flow and salt dissolution through a porous salt simulant bed. More specifically, the test will attempt to establish water accumulation and conditions in which steady state liquid addition/removal occurs.

Considering the exploratory nature and limited scope of this test, no attempt will be made to establish scaling relationships and predictions to a full size tank. The test should, however, provide useful knowledge and elements necessary for defining and performing such scaled tests next fiscal year.

\footnotetext{
Rainbird is a registered trademark of Rain Bird Sprinkler Manufacturing Corporation, Glendora, California.
} 
The saltcake simulant will be placed in a cylindrical polycarbonate container to facilitate visual observation. Water will be dripped in a uniform pattern onto the surface of the saltcake, and saturated liquid will drain out a screened hole in the bottom of the tank (hence simulating retrieval of a saturated solution through a saltwell screen). The rate of water addition will be adjusted to avoid flooding the saltcake.

The physical and chemical parameters that will be measured as a function of time during the test will include:

- water addition rate

- liquid drainage rate

- visual observations of flow patterns

- physical appearance and volume of saltcake

- chemical composition of drained liquid

- polarized light microscopy (PLM) analysis of solids.

In addition, measurements are planned to detect the presence of liquid at various levels within the saltcake.

The test will be run twice - first on a shallow saltcake bed $(5 \mathrm{~cm}$ bed depth) and then on a deeper bed $(25 \mathrm{~cm}$ bed depth), both with the same bed diameter of $30 \mathrm{~cm}$. The first five parameters listed above will be varied and measured with the shallow bed, and all six on the deep bed. The shallow bed test will allow:

- a first and qualitative idea of the scaling effect (the height:diameter ratio of the shallow bed approximates a typical single shell tank saltcake bed);

- an opportunity to make any necessary adjustments to the equipment design before committing the large amount of chemicals needed to prepare the deep bed;

- a chance to evaluate the amount of time it takes to saturate the liquid flowing through the bed, based on comparison of the initial effluent from the shallow bed test and the deep bed test. 
HNF-6519, Rev. 0

\subsection{DESCRIPTION OF TEST}

Simulated saltcake will be prepared by a process similar to the way the actual saltcakes were laid down in the single-shell tanks, through a combination of evaporation and cooling. The test bed will be prepared in a cylindrical polycarbonate container with a diameter and height of $30 \mathrm{~cm}(12 \mathrm{in})$. Enough simulant will be added to the cylindrical container to reach a saltcake height of $5 \mathrm{~cm}(2 \mathrm{in})$ for the shallow bed test, and $25 \mathrm{~cm}$ (10 in) for the deep bed test. The container will be fitted with a metal mesh screen across a hole in the bottom of the container, through which the liquid will be allowed to drain by gravity flow. Dilution water will be added to the top of the saltcake bed through a system of small drippers arranged symmetrically across the surface of the saltcake. Flow rates into and out of the container will be measured throughout the test.

\subsection{Simulant Selection and Composition}

Tank S-102 saltcake was selected as the basis for the composition of the simulant because (a) the saltcake in S-102 is representative of a large fraction of Hanford saltcakes; (b) S-102 saltcake is essentially the same as the saltcake in tanks S-103 and S-105, which are candidates for the first in-tank retrieval tests; and (c) S-102 saltcake has been fully characterized through core sampling.

Two core samples were taken from tank S-102 in 1996. Both core samples (core 125 and core 130) contained 11 segments. Segments 2-8 from both cores contained saltcake. The average analytical results for these segments are shown in Table 2-1.

The first two columns in Table 2-1 show the concentrations of the components in the S-102 core sample saltcake segments (segments 2-8) as reported in the Tank Characterization Report (Anantatmula 1999). The third column shows the components in the form of their assumed species as they are present in the saltcake. The fourth column gives the analyte weight percent (column 2) adjusted for the species weight by multiplying by the appropriate mole weight ratio. For example, $\mathrm{Al}$ is converted to $\mathrm{AlO}_{2}{ }^{-}$by multiplying by the factor [(26.9815+2×15.9994)/26.9815].

The simulant composition cannot follow the S-102 composition perfectly, because the mass and charge balances for the simulant are constrained to be $100 \%$ and 1.00 , respectively. Therefore, some adjustments had to be made. These adjustments are somewhat arbitrary, and any number of combinations could have been used.

Tank BY-106 contains saltcake that is similar to that in S-102, so its composition (last column in Table 2-1) was used as a guide in making the needed adjustments. Except for Na, no component concentration was raised above the concentration found in BY-106. The $\mathrm{Na}$ concentration had to be raised more to bring the charge balance up to 1.00 . The final balanced simulant composition matches the $\mathrm{S}-102$ composition for all species except $\mathrm{K}^{+}$, $\mathrm{Na}^{+}, \mathrm{F}, \mathrm{SO}_{4}{ }^{2-}, \mathrm{C}_{2} \mathrm{O}_{4}{ }^{2-}, \mathrm{CO}_{3}{ }^{2-}$, and $\mathrm{H}_{2} \mathrm{O}$, all of which were raised to increase the mass balance to $100 \%$. 
HNF-6519, Re.v. 0

Table 2-1. Core Sample and Simulant Concentrations in Weight Percent

\begin{tabular}{|c|c|c|c|c|c|}
\hline Analyte & $S-102^{2}$ & Species & $S-102^{b}$ & Simulant & BY $-106^{\circ}$ \\
\hline Al & 1.10 & $\mathrm{AlO}_{2}^{-}$ & 2.40 & 2.40 & 3.50 \\
\hline B & 0.05 & $\mathrm{~B}(\mathrm{OH})_{3}$ & 0.29 & 0.29 & not reported \\
\hline $\mathrm{Ca}$ & 0.03 & $\mathrm{Ca}(\mathrm{OH})_{2}$ & 0.055 & 0.055 & 0.02 \\
\hline $\mathrm{Cr}$ & 0.19 & $\mathrm{Cr}(\mathrm{OH})_{3}$ & 0.38 & 0.38 & 0.22 \\
\hline $\mathbf{F e}$ & 0.13 & $\mathrm{Fe}_{2} \mathrm{O}_{3}$ & 0.19 & 0.19 & 0.03 \\
\hline $\mathbf{K}$ & 0.09 & $\mathbf{K}$ & 0.09 & 0.24 & 0.24 \\
\hline $\mathrm{Na}$ & 22.0 & $\mathrm{Na}$ & 22.0 & 25.54 & 25.0 \\
\hline $\mathrm{Si}$ & 0.04 & $\mathrm{SiO}_{2}$ & 0.086 & 0.086 & 0.04 \\
\hline$F^{-}$ & 0.03 & $\mathrm{~F}$ & 0.03 & 0.62 & 0.62 \\
\hline $\mathrm{Cl}^{-}$ & 0.28 & $\mathrm{Cl}^{-}$ & 0.28 & 0.28 & 0.16 \\
\hline $\mathrm{NO}_{2}^{-}$ & 3.06 & $\mathrm{NO}_{2}^{-}$ & 3.06 & 3.06 & 2.71 \\
\hline $\mathrm{NO}_{3}^{-}$ & 45.6 & $\mathrm{NO}_{3}^{-}$ & 45.6 & 45.6 & 40.5 \\
\hline $\mathrm{PO}_{4}{ }^{3-}$ & 0.99 & $\mathrm{PO}_{4}{ }^{3-}$ & 0.99 & 0.99 & 0.30 \\
\hline $\mathrm{SO}_{4}^{2-}$ & 0.60 & $\mathrm{SO}_{4}^{2-}$ & 0.60 & 1.20 & 1.20 \\
\hline $\mathrm{C}_{2} \mathrm{O}_{4}{ }^{2-}$ & 0.31 & $\mathrm{C}_{2} \mathrm{O}_{4}{ }^{2-}$ & 0.31 & 1.26 & 1.26 \\
\hline TIC & 0.54 & $\mathrm{CO}_{3}^{2-}$ & 2.70 & 3.50 & 7.15 \\
\hline TOC & 0.20 & $\mathrm{CH}_{3} \mathrm{COO}^{-}$ & 0.45 & 0.45 & 0.16 \\
\hline $\mathrm{OH}$ & 0.42 & $\mathrm{OH}$ & 0.42 & 0.42 & 1.14 \\
\hline $\mathrm{H}_{2} \mathrm{O}$ & 13.1 & $\mathrm{H}_{2} \mathrm{O}$ & 13.1 & 13.44 & 14.7 \\
\hline \multicolumn{3}{|c|}{ Mass Balance ${ }^{d}$} & 93.0 & 100.00 & 99.0 \\
\hline \multicolumn{3}{|c|}{ Charge Balance $^{e}$} & 0.94 & 1.000 & 0.94 \\
\hline
\end{tabular}

a Tank Characterization Report (Anantatmula 1999, Table B3-8).

${ }^{b}$ Analyte concentrations converted to weight of assumed species.

${ }^{c}$ BY-106 saltcake composite sample analysis (Herting 1998, Table 8-2).

d Sum of species weights (should equal 100\%; simulant constrained to be $100 \%$ )

- Ratio of cation equivalents to anion equivalents (should equal 1.00; simulant charge balance constrained to be 1.00 ) 


\subsection{Basis for Test Parameters}

As explained earlier, this initial and exploratory test is not intended to be a scale-model demonstration of saltcake retrieval. It is intended to demonstrate patterns of liquid flow and salt dissolution that could occur within the saltcake in the tank.

Figure 2-1 shows a drawing of a typical saltcake layer in a single shell tank, $23 \mathrm{~m}(75 \mathrm{ft})$ in diameter and $4.6 \mathrm{~m}(15 \mathrm{ft})$ thick. The figure shows a typical saltwell reaching to near the bottom of the saltcake. Two small regions labeled as "Test Zone 1" and "Test Zone 2" are drawn in the figure, representing cylindrical regions of saltcake each $30 \mathrm{~cm}(1 \mathrm{ft})$ in diameter and $25 \mathrm{~cm}(10 \mathrm{in})$ thick. The test outlined here is designed to model the behavior of saltcake and liquid flow patterns in one of these test zones. The discussion is focused on the deep bed test.

The behavior of the saltcake in Test Zone 1 is expected to be essentially the same as the behavior in Test Zone 2, provided uniform distribution of water across the surface of the saltcake is maintained. This allows the dimensions of the test saltcake bed (12 in diameter $\mathbf{x}$ 10 in depth) to be selected based on what is reasonable to achieve on the laboratory bench top, while still having enough height to study the chemical properties of the saltcake.

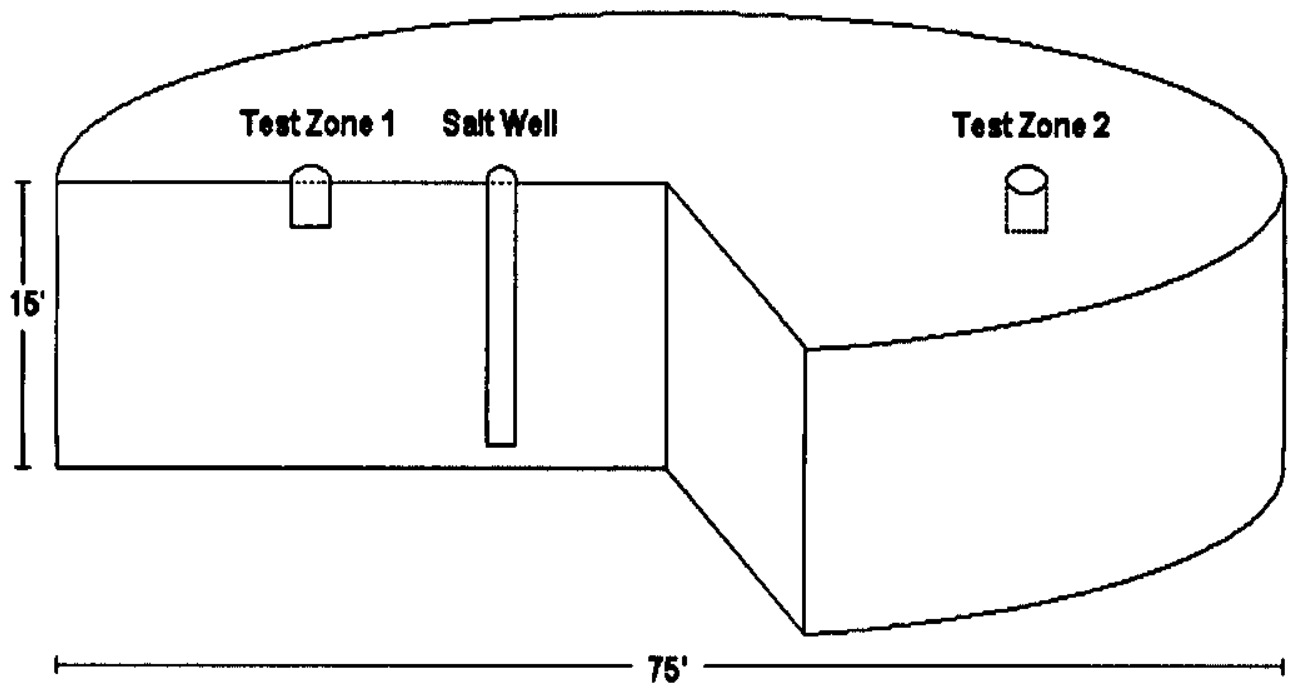

Figure 2-1. Diagram of Saltcake Layer in Single Shell Tank.

(Salt well and test zones not drawn to scale.) 
When the water contacts the top of the saltcake bed, it will begin to dissolve salts as it percolates down through the saltcake. Eventually, the liquid becomes saturated and no longer dissolves salt. The depth at which the liquid becomes saturated is not known, but is speculated to be within a few inches. A test bed depth of 10 inches is believed to be sufficient to ensure that the liquid is saturated when it reaches the bottom of the bed.

The diameter of the test bed $(30 \mathrm{~cm} / 12$ in) is chosen to be large enough to avoid wall effects like channeling of the liquid down the inner wall of the container, while limiting the amount of simulant needed to fill the container. At the design diameter and depth, it will take approximately 18 liters of simulated saltcake to fill the container.

\subsection{Instrumentation and Measurements}

The test will be filmed with a video camera in time-lapse mode. Some of the parameters listed in Section 1.0 can be viewed directly from the videotape. These include visual observations of flow patterns, and physical appearance and volume of saltcake.

Water addition rate and liquid drainage rate will be tracked by recording the liquid levels in the water addition reservoir and in the drainage collection bottles. In addition, the pump used to deliver the dilution water will be calibrated to determine its flow rate. The flow rate will be adjusted as needed to avoid flooding the saltcake (developing a layer of standing liquid above the top of the saltcake bed).

An attempt will be made to develop an "instrument tree" to record the height of liquid within the saltcake bed (which may or may not be visually apparent). In the actual single shell tanks, a neutron monitor is used to determine this height, but this technique is not practical for application in the laboratory. Some of the techniques we are considering include measurements of conductivity, resistivity, Raman spectra (via fiber optic probes), and pressure differential. If we succeed in developing a method to distinguish between wet and dry saltcake, appropriate sensors will be located at roughly $5 \mathrm{~cm}(2$ in) intervals along a vertical rod or pipe located at the center of the container, assuming the drain hole is located off center.

Chemical analyses will be performed on the water-soluble fraction of the original saltcake simulant and on selected fractions of drained liquid. From these analyses, an overall mass balance will be calculated, as well as dissolution profiles for each of the water-soluble salts. Analyses will be comprehensive enough to perform mass balance and charge balance quality checks. The analyses will include: 
- specific gravity (SpG)

- free hydroxide (OH)

- ion chromatography (IC) for $\mathrm{F}, \mathrm{Cl}^{-}, \mathrm{NO}_{2}{ }^{-}, \mathrm{NO}_{3}{ }^{-}, \mathrm{PO}_{4}{ }^{3-}, \mathrm{SO}_{4}{ }^{2-}$, and $\mathrm{C}_{2} \mathrm{O}_{4}{ }^{2-}$

- inductively coupled plasma spectroscopy (ICP) for metals

- total inorganic carbon/total organic carbon (TIC/TOC)

- percent water by gravimetry $\left(\% \mathrm{H}_{2} \mathrm{O}\right)$

Various chemical salts are expected to dissolve at different rates. Some of the less soluble species (e.g. fluoride, phosphate, and sulfate salts) may even dissolve near the top of the bed and re-precipitate lower in the bed as the ionic strength of the percolating solution increases. Thus, the chemical composition of the saltcake bed is subject to change as a function of time during the test. Periodically during the test, samples of the saltcake will be taken for polarized light microscopy (PLM) to monitor these changes in a qualitative way.

\subsection{Changing the Test}

Minor changes that do not change the expected outcome of the tests may be undertaken by the cognizant scientist without further authorization. Changes that may have minor effects on the expected outcome will be authorized by agreement between the cognizant scientist and the customer technical representative by electronic mail or other written means. Changes that will likely result in substantial changes to the experimental outcome must be approved by formal revision of this test plan. 
HNF-6519, Rer.O

\subsection{DATA INTERPRETATION}

\subsection{Physical Data}

Water addition flow rate and liquid drainage flow rate will be monitored constantly during the test. The time required to achieve steady state flow will be a key measurement of the test. To the extent possible (except for intentional changes to accommodate plugging or channeling effects), the liquid drainage rate will be controlled by gravity flow, and the water addition rate will be adjusted to match the drainage rate to maintain a constant level of liquid within the saltcake bed. The drainage rate is expected to vary with the depth of the saltcake bed, the composition of the material remaining in the bed (e.g. percent insoluble material), and the changes in pore size as solids dissolve or precipitate.

If the drain becomes plugged, air pressure or vacuum can be applied through the bottom of the drain to dislodge the plug. If severe channeling develops, visual flow patterns will be evaluated to determine the cause of the channeling. Small samples of the saltcake material adjacent to the channels may be taken for PLM analysis to determine the composition and appearance of the material that lines the walls of the channels. The saltcake bed may be mixed to disrupt the channels, after which the test would be resumed to see whether the channeling develops again.

\subsection{Chemical Data}

Chemical analyses of initial saltcake and at least six fractions of the drained liquid will be used to develop an understanding of the physical data. (In addition, for the shallow bed test, at least two fractions of the drained liquid will be analyzed.) From the mass balance calculations, it will be possible to determine the composition of the undissolved portion of the saltcake as a function of time. It should also be possible to evaluate whether the drained liquid has reached chemical equilibrium with the saltcake.

Two types of dissolution profiles will be plotted for each analyte, from which it can be shown how the composition of the drained liquid varies. One of these plots will show the concentration of each analyte in the drained liquid, in $\mathrm{mg} / \mathrm{L}$, as a function of the total volume of liquid collected. The other plot will show on the y-axis the amount of each analyte recovered in the drained liquid as a percentage of the total amount present in the original saltcake. The $\mathrm{x}$-axis will again be the total volume of liquid collected. Both of these types of dissolution profile plots have been reported for small batch samples of actual saltcake from tank BY-102, and analogous plots based on a slightly different procedure have been reported for small batch samples of actual saltcake from tank S-102 (Herting 1999).

\subsection{Quality Assurance}

This test plan is assigned Approval Designator E. Approval signatures are required from the authors, the Technical Operations and Process Science (TOPS) manager, the Analytical Services Environmental Compliance officer, and the customer's technical representative. 
HNF-6519, Rev. 0

Detailed laboratory test procedures will be prepared from the general description provided in this document. These test procedures will be reviewed and approved by the TOPS manager and the Analytical Services Safety officer prior to initiation of testing. The instructions, data, and observations will be recorded in a controlled laboratory notebook. All testing will follow the process chemistry quality assurance plan (Meznarich 1996).

\subsection{SAFETY}

The safety requirements that apply to this test plan are described in Laboratory Operating Procedure LO-140-100, "Development of Instrumentation, Methods and Performance of Process Testing". The detailed Test Procedure based on this plan will be approved by the Analytical Services Safety officer.

\subsection{WASTE HANDLING}

This test program is expected to generate approximately 50 liters of dissolved saltcake and approximately 1 liter of undissolved sludge. These will be combined and saved in a plastic carboy for possible use in Fiscal Year 2001 for additional testing on this same project. If funding for the 2001 testing does not develop, or if the saved material is deemed unsuitable for the additional testing, then the saved material will be declared hazardous waste, which will be handled in accordance with Laboratory Operating Procedure LO-110-129, "Waste Collection and Disposal in 222-SA". A waste stream fact sheet for the pre-designated waste is attached as Appendix A. A Waste Compatibility Assessment is attached as Appendix B.

No other regulated waste stream will be generated by this activity. Should any spills occur, they would be handled in accordance with "222-S Spill and Release Reporting", WMH-310 Section 4.15, Rev. 1, October 22, 1998. 
HNF-6519, Rev. 0

\subsection{SChedule AND DeLiVERABles}

This Test Plan is scheduled to be issued by July 12, 2000. Management approval for the specific laboratory instructions (Test Procedure) will be obtained by July 30, 2000. Laboratory work will commence by August 1, 2000.

A complete report of the test results will be issued and cleared as a publicly released document by September 30, 2000. Informal interim status reports will be issued to the customer's technical representative via electronic mail no less frequently than every two weeks.

\subsection{REFERENCES}

Anantatmula, R. P. (1996), and S. R. Wilmarth, Tank Characterization Report for SingleShell Tank 241-S-102, HNF-SD-WM-ER-611, Rev. 1, Lockheed Martin Hanford Corporation, Richland, Washington.

Bell, K. E. (1996), J. Franklin, J. Stroup and J. L. Huckaby, Tank Characterization Report for Single-Shell Tank 241-BY-106, WHC-SD-WM-ER-616, Rev. 0, Westinghouse Hanford Company, Richland, Washington.

Herting, D. L. (1999), D. W. Edmonson, J. R. Smith, T. A. Hill and C. H. Delegard, Saltcake Dissolution FY 1999 Status Report, HNF-5193, Rev. 0, Fluor Daniel Hanford, Inc., Richland, Washington.

Meznarich, H. K. (1996), Process Chemistry \& Statistics Quality Assurance Plan, WHC-SD-CP-QAPP-018, Rev. 0, Westinghouse Hanford Company, Richland, Washington.

Wiersma, B. J. (1996), An Investigation of Density Driven Salt Dissolution Techniques, WSRC-TR-96-0160 (U), Westinghouse Savannah River Company, Aiken, South Carolina.

Wiersma, B. J. (January 30, 1997), Laboratory Demonstration of Hanford Dissolution Process, Inter-office Memorandum SRT-MTS-96-2003, Westinghouse Savannah River Company, Aiken, South Carolina. 
HNF-6519, Rev. 0

\section{APPENDIX A: WASTE STREAM FACT SHEET}

\section{2-S LABORATORY}

\section{DEVELOPMENTAL METHOD WASTE STREAM FACT SHEET}

\begin{tabular}{|c|c|c|}
\hline $\begin{array}{l}\text { Constituents of } \\
\text { Waste Generated }\end{array}$ & CAS Number & $\begin{array}{l}\text { Approximate } \\
\text { Weight } \%\end{array}$ \\
\hline sodium aluminate & $1302-42-7$ & 3.3 \\
\hline boric acid & $10043-35-3$ & 0.3 \\
\hline calcium hydroxide & $1305-62-0$ & 0.06 \\
\hline chromium(III) oxide & $1308-38-9$ & 0.3 \\
\hline ferric oxide & $1309-37-1$ & 0.2 \\
\hline silicon dioxide & $7631-86-9$ & 0.1 \\
\hline sodium fluoride & $7681-49-4$ & 1.4 \\
\hline sodium chloride & $7647-14-5$ & 0.5 \\
\hline sodium nitrate & $7631-99-4$ & 62. \\
\hline potassium nitrate & $7757-79-1$ & 0.6 \\
\hline sodium nitrite & $7632-00-0$ & 4.6 \\
\hline sodium phosphate, 12-hydrate & $7601-54-9$ & 4.0 \\
\hline sodium sulfate & $7757-82-6$ & 1.8 \\
\hline sodium oxalate & $62-76-0$ & 1.9 \\
\hline sodium acetate & $127-09-3$ & 0.6 \\
\hline sodium carbonate & $497-19-8$ & 6.2 \\
\hline sodium hydroxide & $1310-73-2$ & 1.0 \\
\hline reagent water & $7732-18-5$ & 11. \\
\hline Waste Codes: D001 + D002 + D007 & \multicolumn{2}{|c|}{ Waste Class: Dangerous } \\
\hline Disposal: Labpack & \multicolumn{2}{|c|}{ Waste Container: Plastic } \\
\hline \multicolumn{3}{|l|}{ Comments: $\mathrm{pH}>12$} \\
\hline \multicolumn{3}{|c|}{$\begin{array}{l}\text { Intended Use: } \\
\text { Solubility tests of simulated tank waste saltcake. }\end{array}$} \\
\hline \multicolumn{3}{|c|}{ Approvals - Print Name, Sign, and Date } \\
\hline \multicolumn{3}{|l|}{ Authored By J. C. Person } \\
\hline \multicolumn{3}{|l|}{$\begin{array}{l}\text { Environmental Compliance } \\
\text { Officer (or Delegate) } \\
\text { R. J. Boom }\end{array}$} \\
\hline
\end{tabular}

Waste Stream Labeling Requirements: (Waste Stream type, container type, waste codes, and disposal criteria are required.) Waste class is optional. The label is considered to be an example label, but contains the required information for waste stream identification. other hazardous waste labeling requirements may apply

\begin{tabular}{|l|}
\multicolumn{1}{|c|}{ DEVELOPMENTAL METHOD } \\
WASTE STREAM LABEL \\
\hline Waste Stream Type: Liquid + Solid, Alkaline \\
Waste Container: Plastic \\
Waste Codes: D00I+D $0(2+1) 007$ \\
Waste Class: Dangerous \\
Disposal Criteria: Labpack \\
I I Mark if waste has No'T been in contact with rank \\
Farm Waste \\
\hline
\end{tabular}

\begin{tabular}{|c|c|c|c|c|c|}
\hline Procedure No. & Rev-Mod & $\begin{array}{c}\text { Developmental } \\
\text { Method No }\end{array}$ & Waste Stream Type & $\begin{array}{c}\text { Waste Stream } \\
\text { No. }\end{array}$ & Page No. \\
\hline I.0-140-100 & $(-3$ & lNF-6519 & Liquid +Solid, Alkaline & 1 of 1 & 1 of I \\
\hline
\end{tabular}




\section{APPENDIX B: WASTE COMPATIBILITY REVIEW}

\section{Compatibility Review}

Compatibility, in this case, means that two or more substances can be mixed with no adverse effects occurring over an extended period. Incompatibility means contact of two or more substances could result in an explosion, an unexpected rapid evolution of gases or the emission of substances that are highly toxic and/or flammable.

PROCEDURE NUMBER: Test Plan HNF-6519
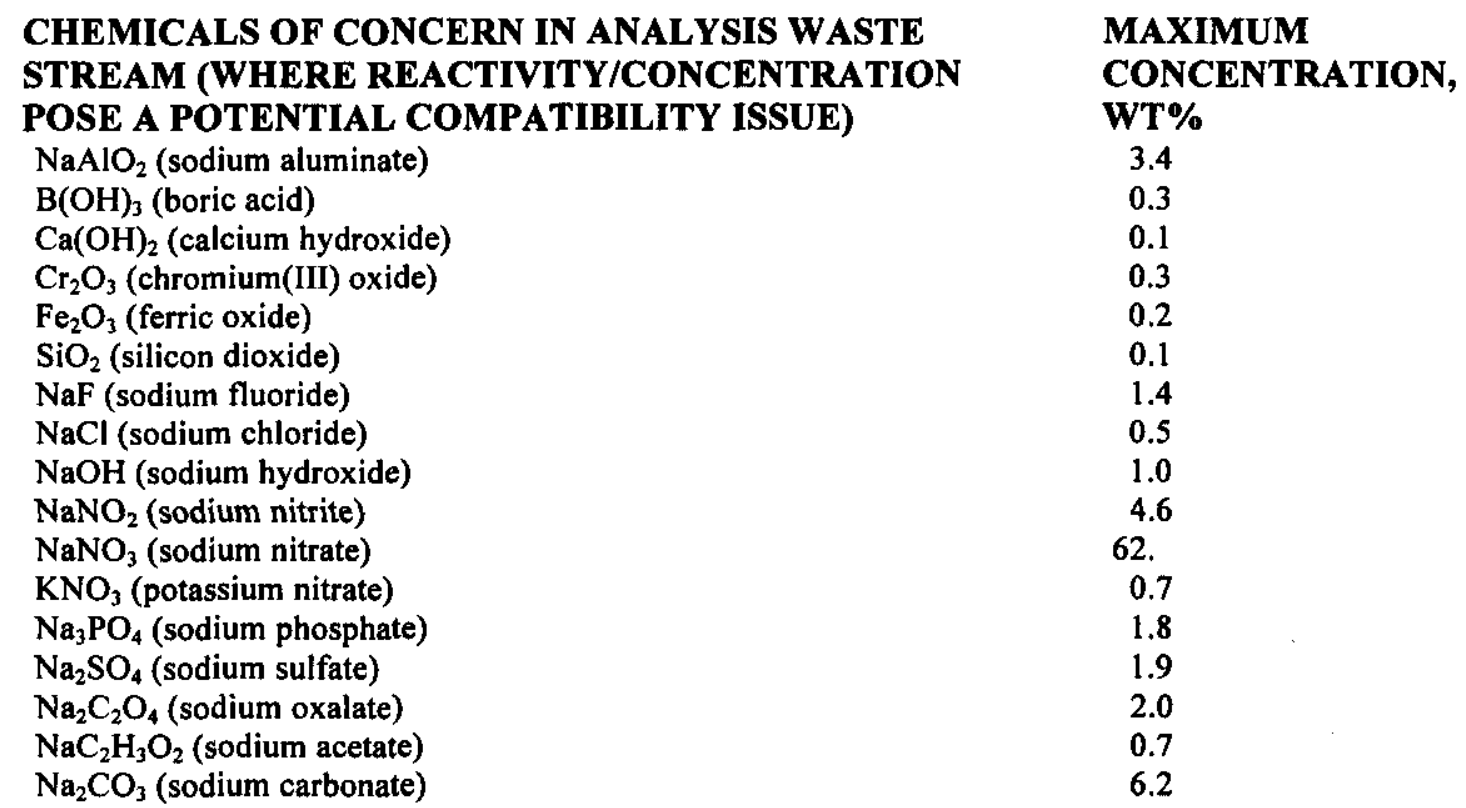

COMPATIBILITY HAZARDS, INCLUDING SPECIAL STORAGE REQUIREMENTS, POSIBLE REACTIONS, AND RESULTS OF MIXING INCOMPATIBLE WASTE STREAMS:

The waste is alkaline ( $\mathrm{pH}$ is 13 or larger), so mixing with acid will generate heat and possibly boil/bump the liquid phase.

RECOMMENDED WASTE STREAMS:

One liquid + solid (slurry) waste stream.

CONTAINER(S) MATERIAL:

Plastic

REFERENCE DOCUMENTS USED IN THE COMPABILITY STUDY: Sax, et al., Dangerous Properties of Industrial Materials, $7^{\text {th }} \mathrm{ed}$.
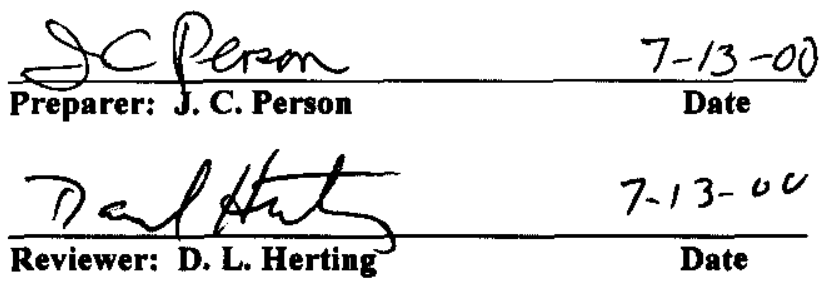


\section{DISTRIBUTION SHEET}

\begin{tabular}{|l|l|}
\hline To & From \\
Distribution & TOPS \\
\hline
\end{tabular}

\section{Project TitleNWork Order}

HNF-6519, "Test Plan for Simulated Saltcake Retrieval Test

\section{Name}

D. B. Bechtold

R. J. Boom

P. J. Certa

A. F. Choho

D. W. Crass

V. F. Fitzpatrick

J. S. Garfield

D. L. Herting

J. R. Jewett

E. A. Pacquet

J. C. Person

C. M. Seidel

W. J. Stokes

J. K. Watts

W. I. Winters

Central Files
Page of

Date July 14, 2000

EDT No. 620372

ECN No. N/A

\begin{tabular}{|c|c|c|c|c|}
\hline MSIN & $\begin{array}{l}\text { Text } \\
\text { With All } \\
\text { Attach. }\end{array}$ & Text Only & $\begin{array}{l}\text { Attach/J } \\
\text { Appendix } \\
\text { Only }\end{array}$ & $\begin{array}{c}\text { EDT/ECI } \\
\text { Only }\end{array}$ \\
\hline
\end{tabular}

